
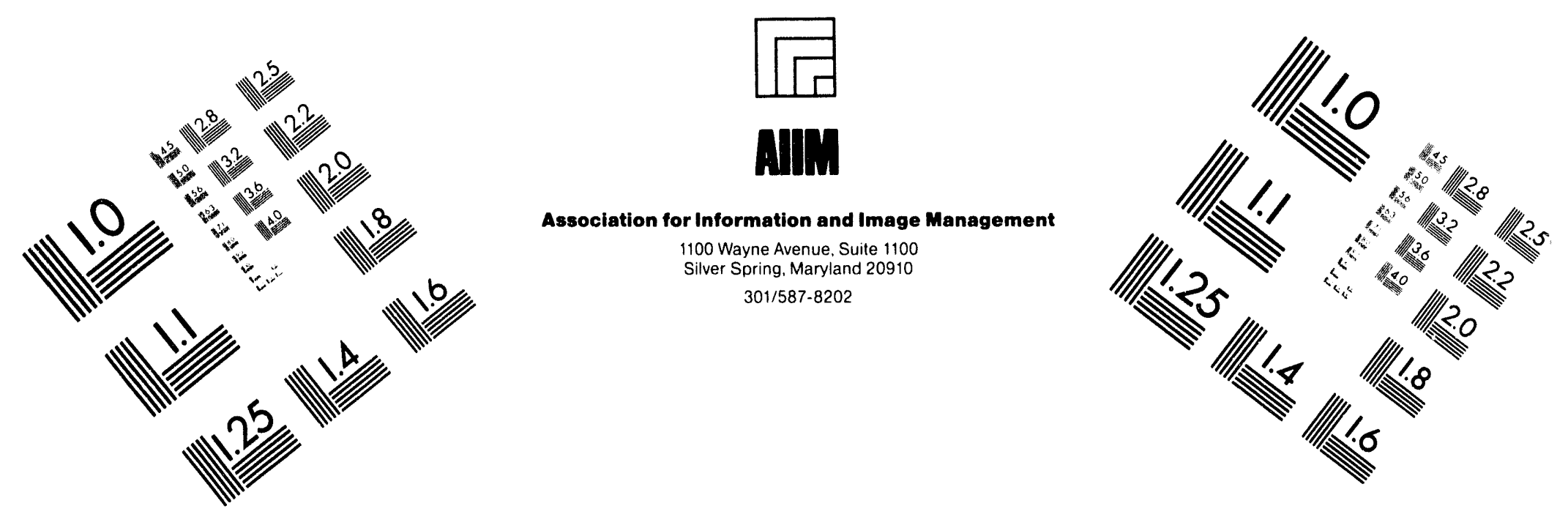

\title{
Centimeter
}

| Inches
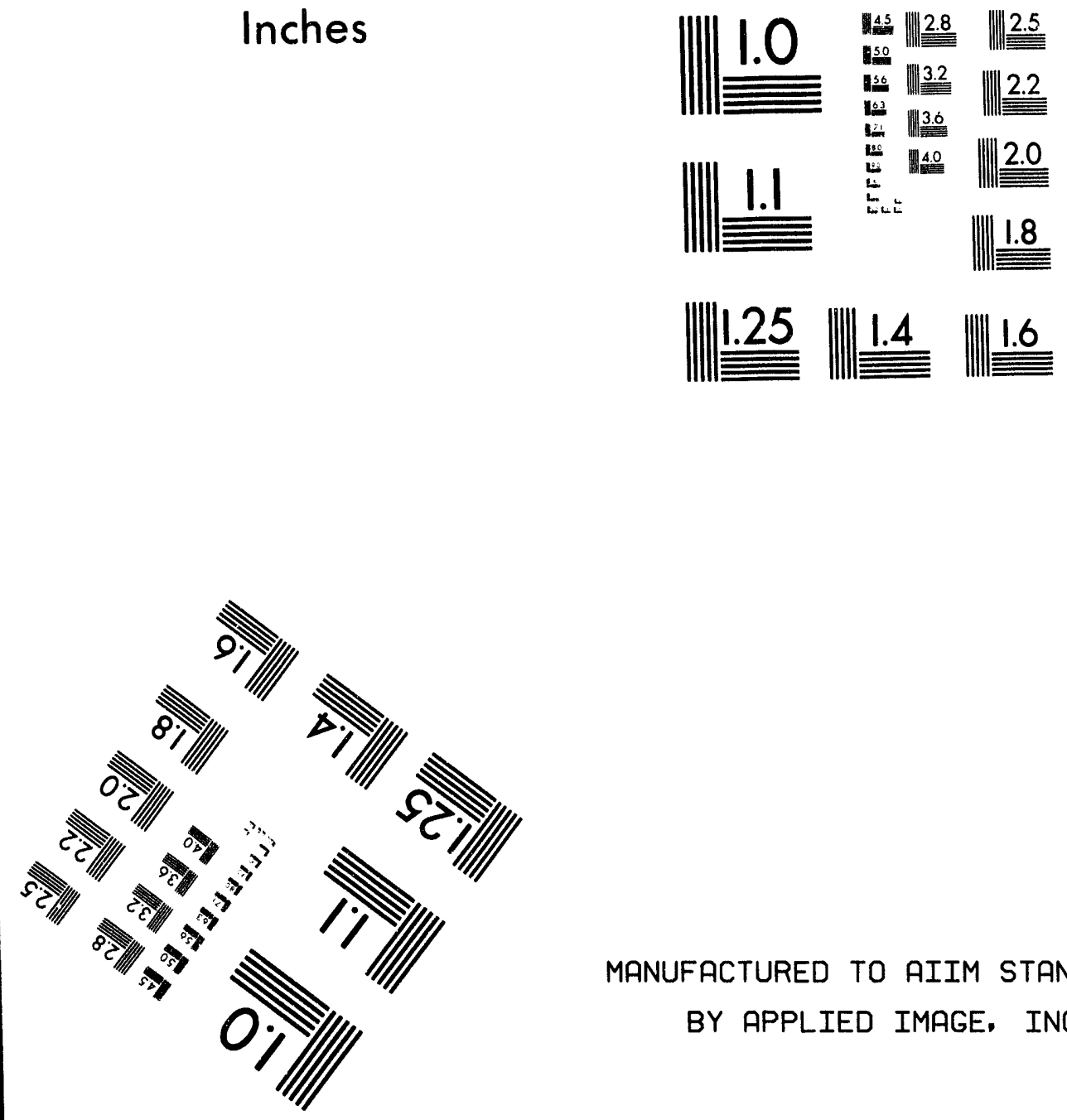

MANUFACTURED TO AIIM STANDARDS

BY APPLIED IMAGE, INC.

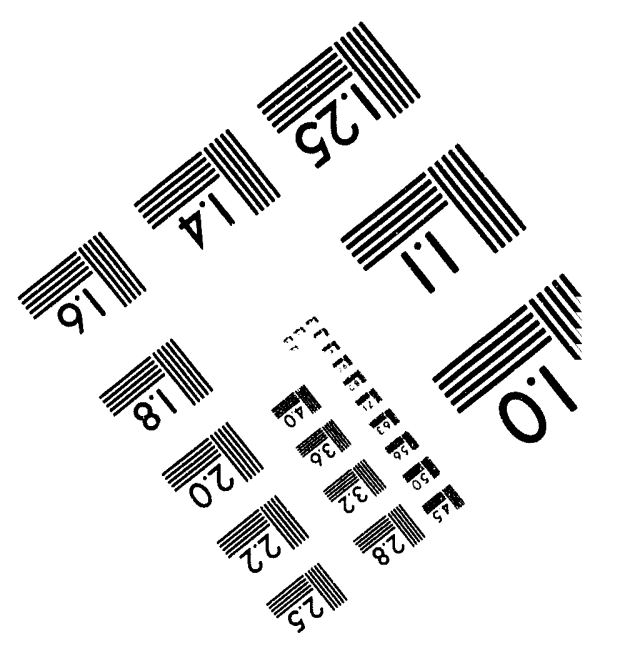



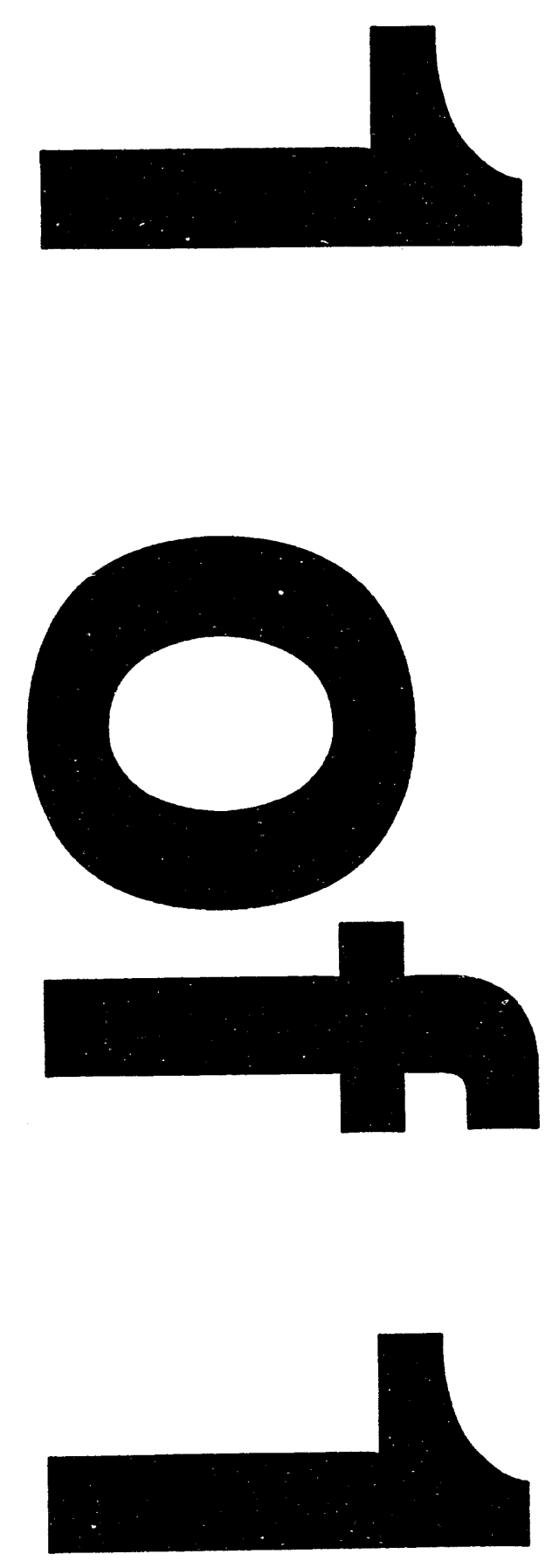


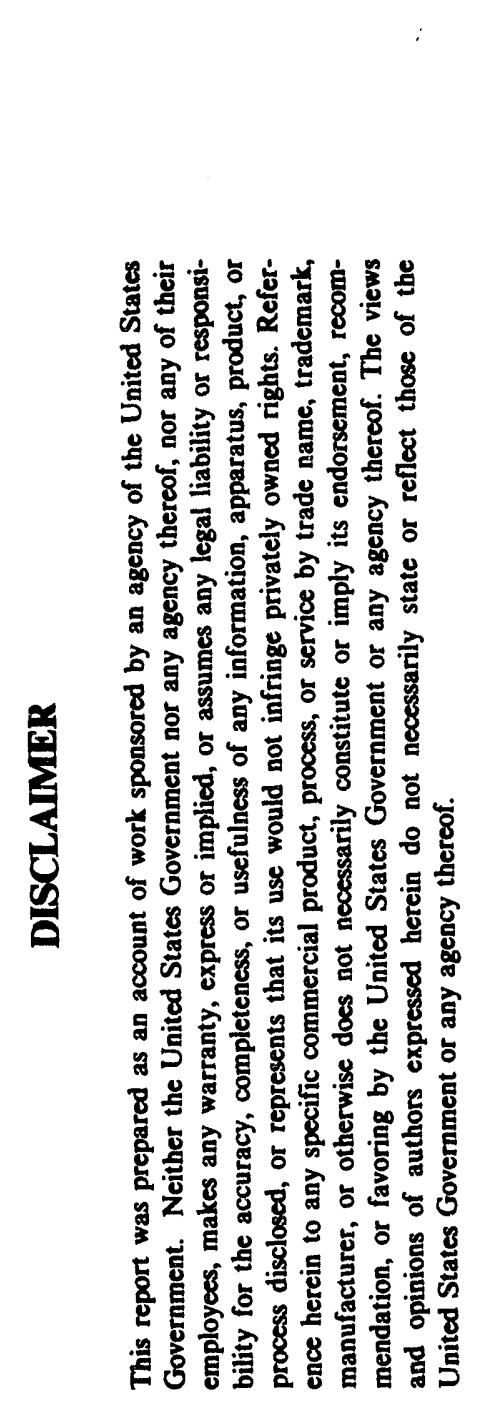

\section{MAGNETOTELLURIC MAPPING} OF UPPER CRUSTAL ISOTHERMS BENEATH THE VALLES CALDERA HYDROTHERMAL SYSTEM

\author{
GEORGE R. JIRACEK \\ CHRISTOPHER L. KINN \\ CLARK L. SCOTT \\ SCOTT A. CURRAN \\ SAN DIEGO STATE UNIVERSITY \\ AND \\ MARTHA G. KUYKENDALL \\ CALIFORNIA INSTITUTE OF TECHNOLOGY \\ FALL AGU
SAN FRANCISCO \\ 1993
}

\begin{abstract}
Magnetotelluric (MT) soundings across the western margin of the Valles Caldera hydrothermal system in New Mexico have revealed a striking correlation between depth of the electrically conductive portion of the upper crust and isotherms projected from deep geothermal test wells. The crust is highly resistive ( $\approx 1000 \mathrm{ohm}-\mathrm{m}$ ) in the range of 2 to $4 \mathrm{~km}$ depth where temperatures of over $300^{\circ} \mathrm{C}$ have been logged in test wells. However, at greater depths the upper crust becomes increasingly conductive; in this range, the conductivity contours closely match the projected isotherms. The inferred geoelectric section was obtained by two-dimensional inversion after shallow threedimensional distortion corrections were applied to the data. Inversions were constrained to depths as great as $4 \mathrm{~km}$ by borehole electric logs which were highly compatible with the nearby MT soundings.

Possible reasons for the positive correlation between the conductive depth patterns and the isotherms are: 1) fluid accumulation within the thermally controlled brittle-ductile transition and 2) a halo of conductive mineralization (e.g., connected sulfide films) surrounding a still cooling, shallow intrusive.
\end{abstract}




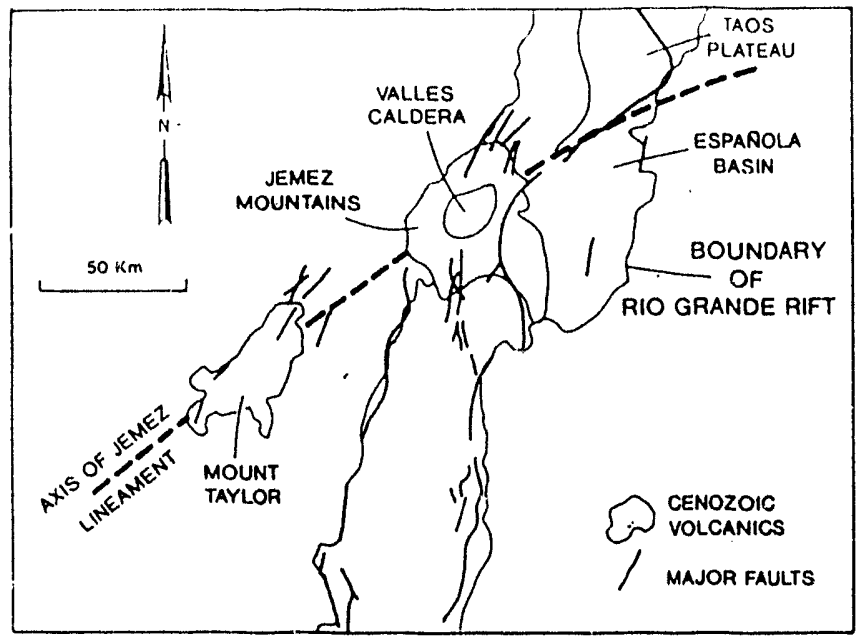

VALLES CALDERA REGION

(AFTER GOFF ET AL., 1992)

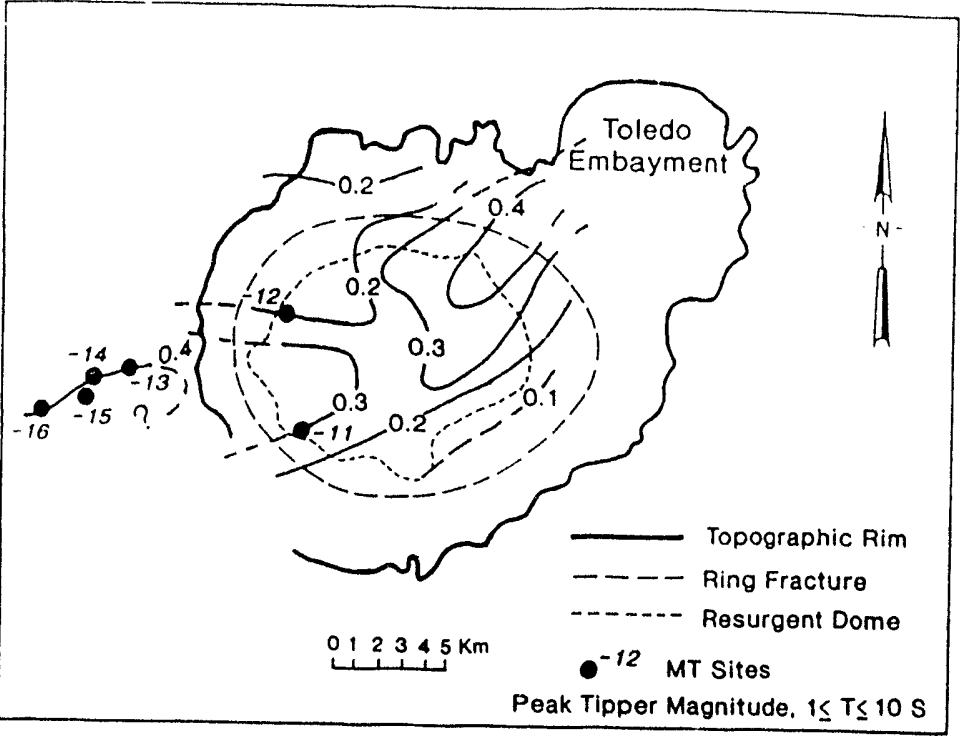

VALLES CALDERA

MT SITES AND TIPPER MAGNITUDE

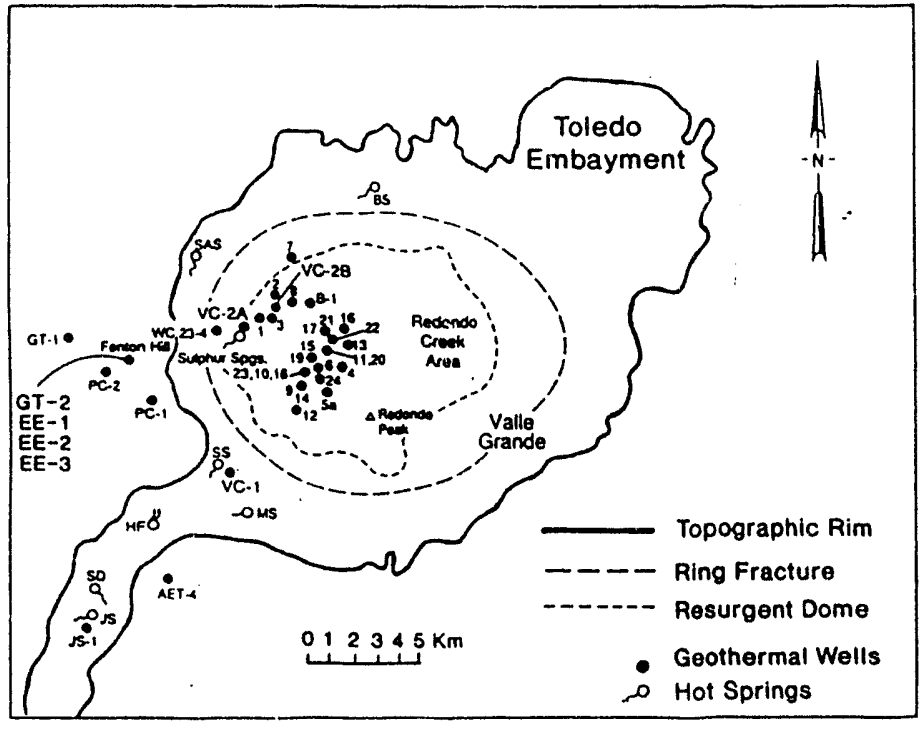

VALLES CALDERA

GEOTHERMAL WELLS AND HOT SPRINGS

(GOFF ET AL.. 1992)

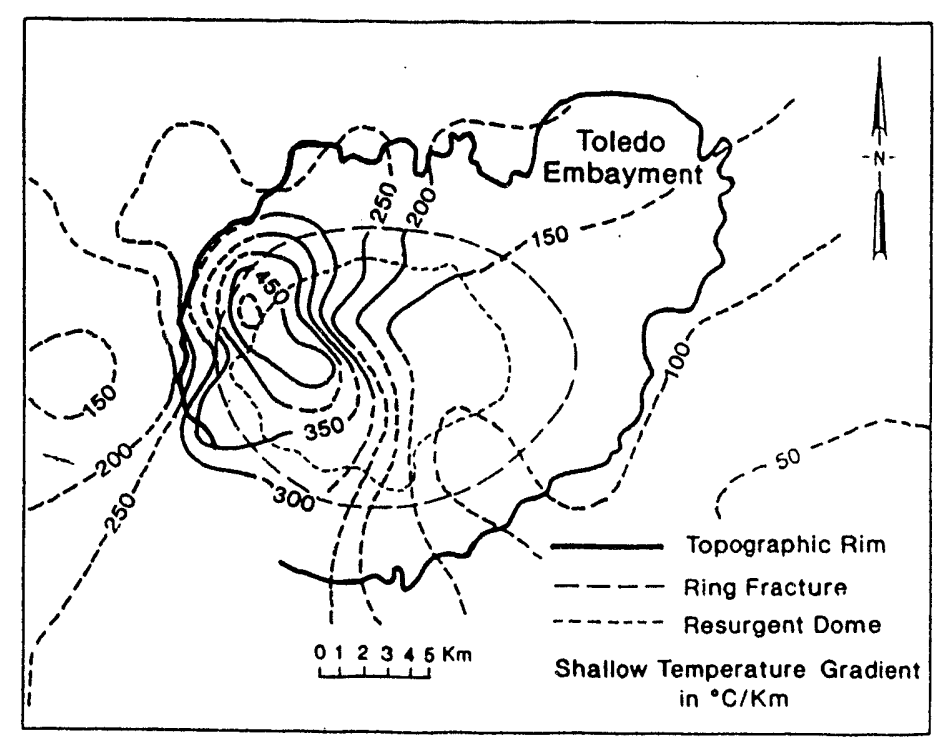

VALLES CALDERA

TEMPERATURE GRADIENT MAP (SASS AND MORGAN, 1988) 


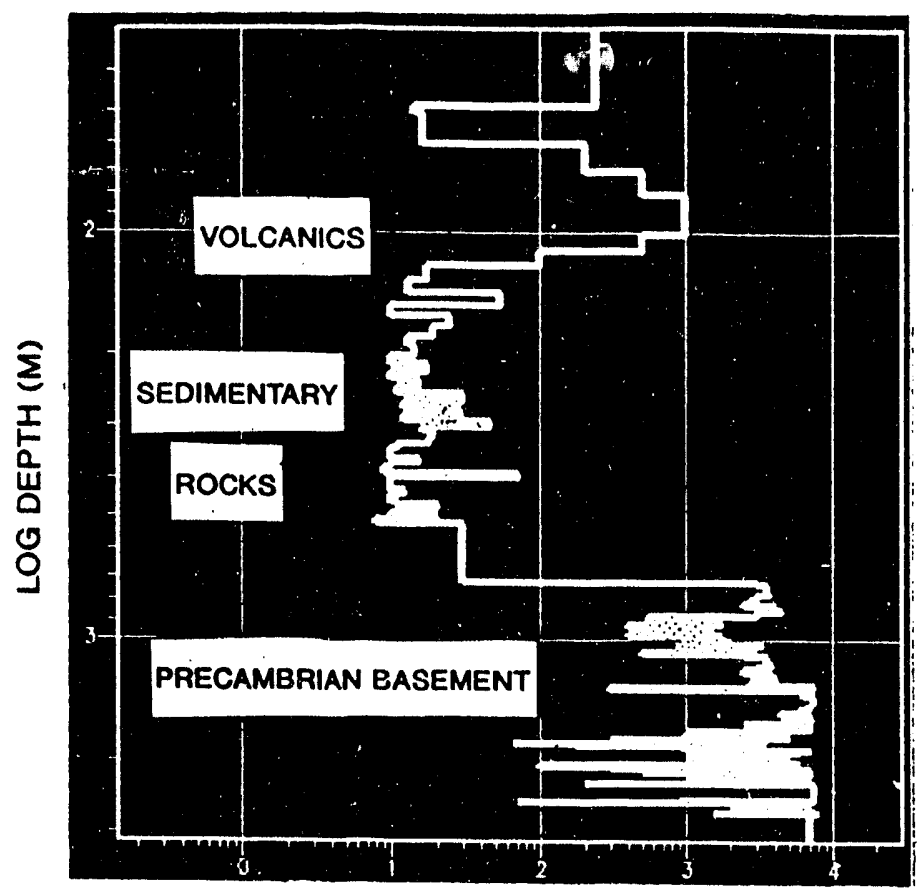

LOG RESISTIVITY (OHM-M)

GT-2 BOREHOLE E LOG

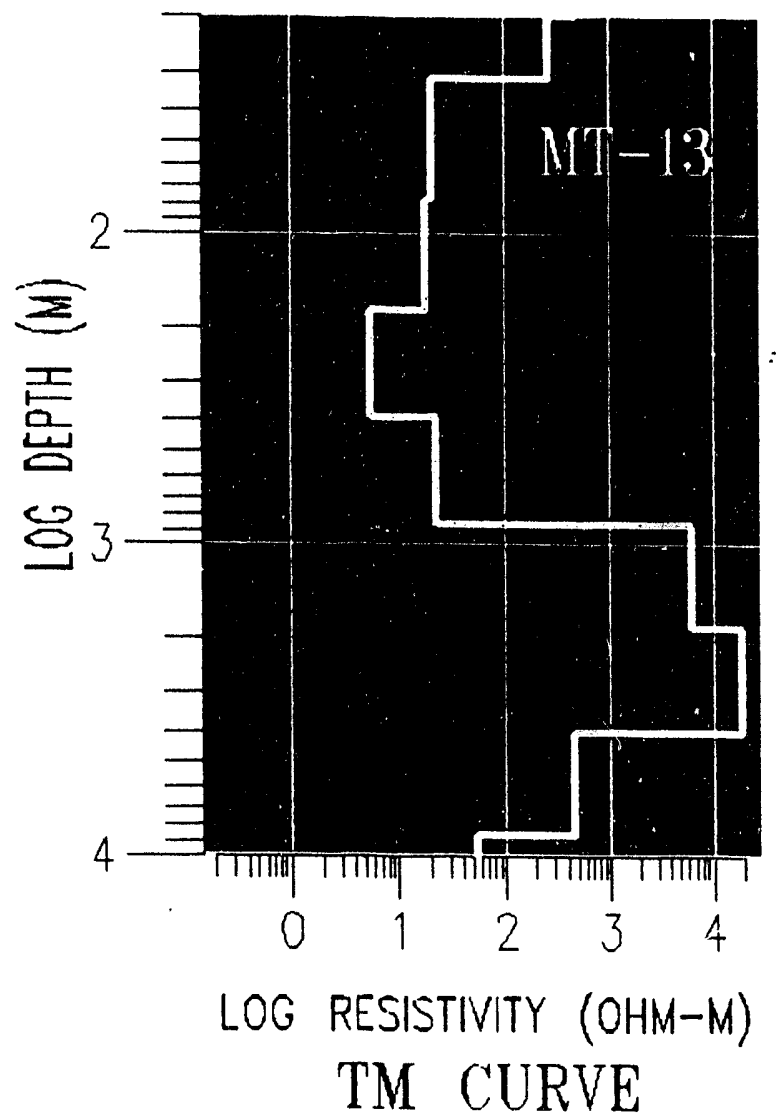

1-D INVERSE MODEL
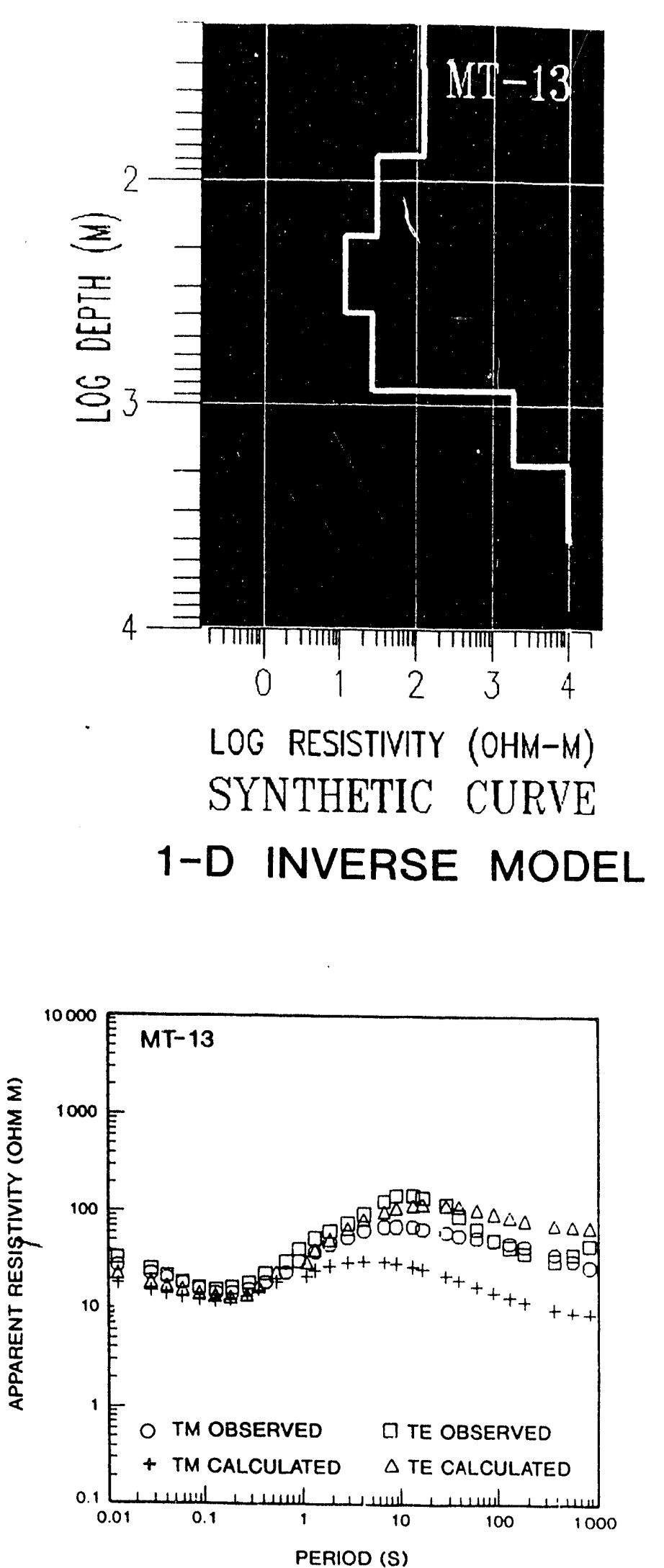

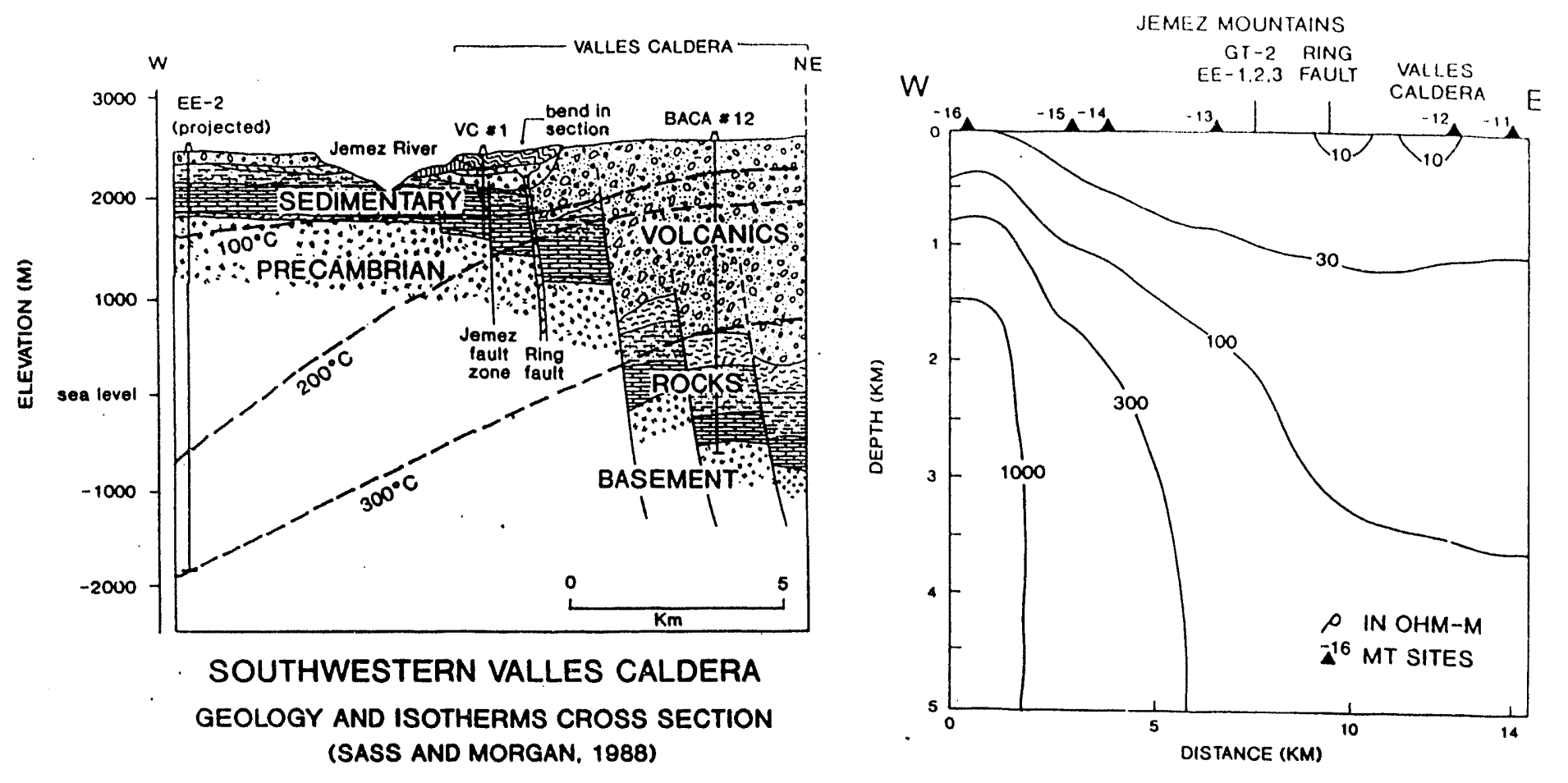

2-D GEOELECTRIC SECTION

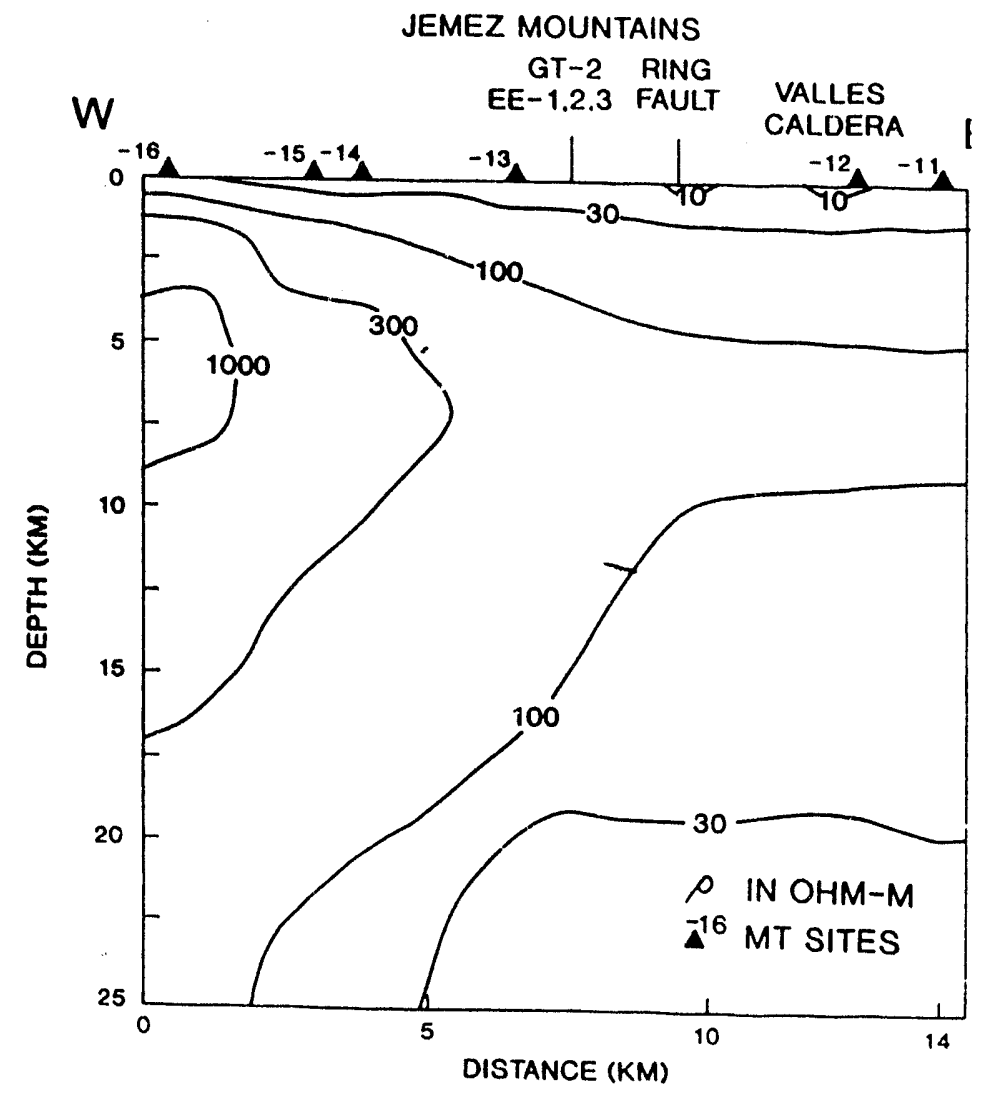

\section{2-D GEOELECTRIC SECTION}




\section{CONCLUSIONS}

GROOM-BAILEY ANALYSIS REQUIRED

STANDARD (SWIFT) ANALYSIS INADEQUATE

1-D AND 2-D GEOELECTRIC MODELS

UPPER $5 \mathrm{KM}$

STRONGLY CORRELATES WITH BOREHOLE DATA

DISTINCT CONTRAST BETWEEN

HOT-WATER-SATURATED VOLCANICS/SEDIMENTARY

AND

ROCKS (<100 OHM-M)

PRECAMBRIAN BASEMENT (>100 OHM-M)

DEEP CRUST (5-25 KM)

DEPTH TO CRUSTAL CONDUCTIVE ZONE MATCHES PROJECTED ISOTHERMS

POSSIBLY CONTROLLED BY $<100$ KA MAGMATIC EVENT

ROLES OF BRITTLE-DUCTILE TRANSITION, PARTIAL MELT, WATER, AND CONDUCTIVE MINERALS (E.G., GRAPHITE, ILMENITE, SULPHIDES) UNCERTAIN

POSSIBLE ASSOCIATION WITH DIHEDRAL ANGLE $\mathrm{H}_{2} \mathrm{O}$ WETTING

DIHEDRAL ANGLE IMPLICATIONS

IN METAMORPHIC ROCKS

\begin{tabular}{|c|c|c|c|}
\hline $\begin{array}{c}\text { SCHEMATIC } \\
\text { SINGLE GRAIN } \\
\text { WATER } \\
\text { DISTRIBUTION }\end{array}$ & \multicolumn{3}{|c|}{ DEEP CRUSTAL PROPERTIES } \\
\cline { 2 - 4 } & WATER & ELECTRICAL & RHEOLOGICAL \\
\hline & ISOLATED & RESISTIVE & $\begin{array}{c}\text { LOW } \\
\text { STRAIN RATE }\end{array}$ \\
\hline$\Theta \geq 60^{\circ}$ & CONNECTED & CONDUCTIVE & $\begin{array}{c}\text { HIGH } \\
\text { STRAIN RATE }\end{array}$ \\
\hline$\Theta \leq 60^{\circ}$ & & & \\
\hline
\end{tabular}



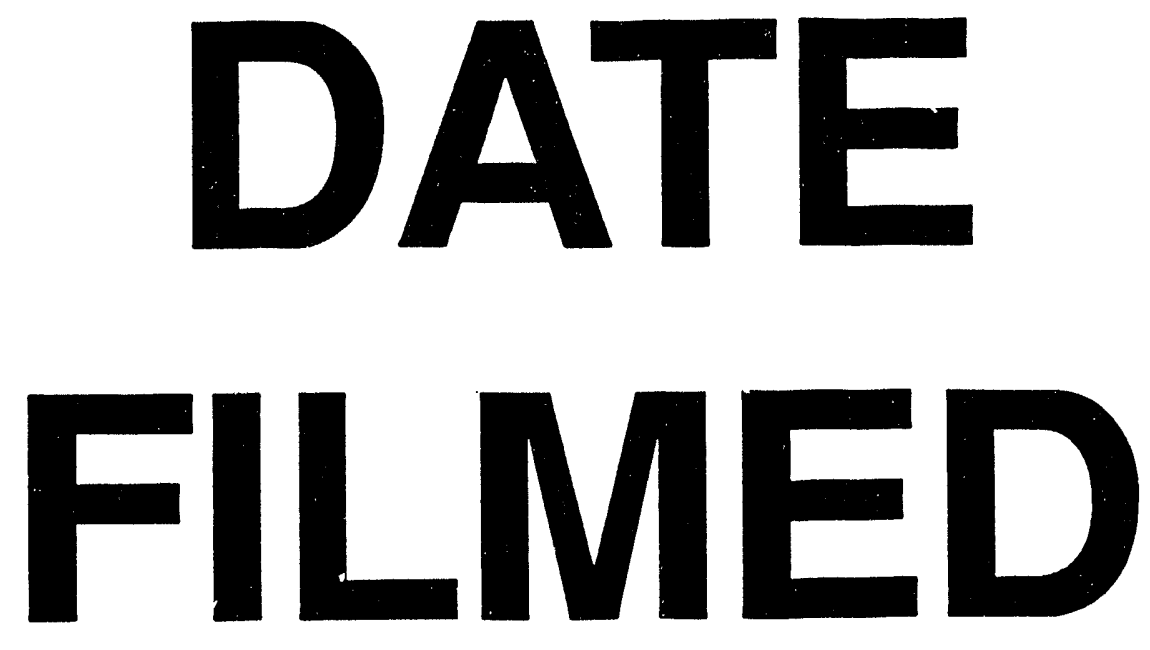

$$
10 / / 9 / 94
$$
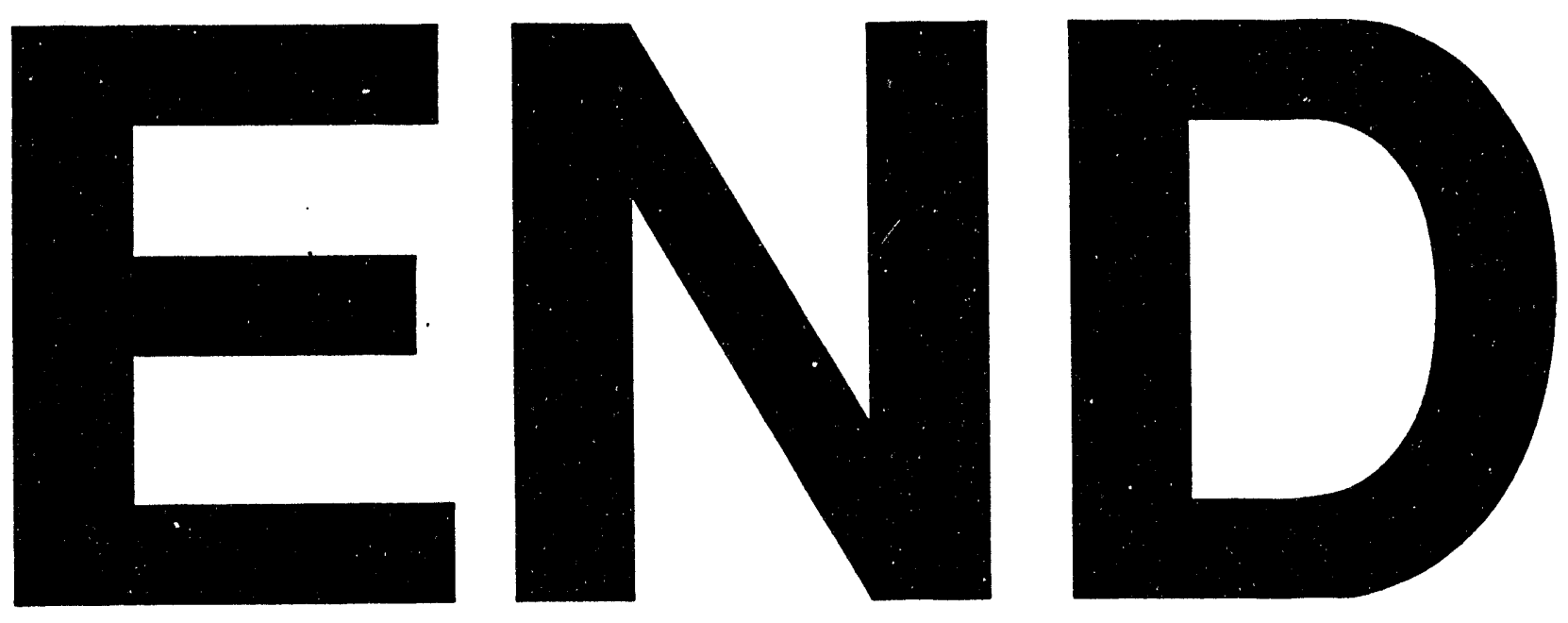
